\title{
A betegelégedettséget befolyásoló tényezők és a lojalitás vizsgálata a háziorvosi ellátásban
}

\author{
Juhász Zoltán - Hetesi Erzsébet - Buzás Norbert \\ Szegedi Tudományegyetem
}

\begin{abstract}
A TANULMÁNY CÉLJA
Tanulmányunk a háziorvosi ellátással kapcsolatos betegelégedettséget, annak befolyásoló tényezőit, és az elégedettség-lojalitás összefüggését vizsgálja. Arra keressük a választ, hogy az alapellátással kapcsolatos betegelégedettségre mely szolgáltatásminőség tényezők hatnak leginkább, és az elégedettség befolyásolja-e a háziorvoshoz való hủség kialakulását, a lojalitást.
\end{abstract}

\begin{abstract}
ALKALMAZOTT MÓDSZERTAN
A háziorvosi ellátással kapcsolatos betegelégedettség személyes kérdőíves felméréssel történt, ahol nemzetközi és hazai kutatásokban validált kérdéssorokat használtunk. A minta kiválasztása három városban történt nem véletlen módszerrel. Az adatok feldolgozására SmartPLS és IBM SPSS Statistics 24 programot alkalmaztunk. A minta jellemzése leíró statisztikai mutatókkal történt, a változók közötti összefüggéseket matematikai statisztikai eljárásokkal - leíró statisztikával, egyszempontos variancia-analízissel, valamint PLS útelemzéssel vizsgáltuk.
\end{abstract}

\section{LEGFONTOSABB EREDMÉNYEK}

Az elégedettség átlagos értékei többnyire egybecsengenek a hazai kutatási eredményekkel. A megkérdezettek $80 \%$-a összességében elégedett vagy nagyon elégedett volt a háziorvosával, az ötfokozatú Likertskála szerint átlagosan 4,27-re értékelték a teljesítményüket. A PLS-útelemzés útegyütthatói alapján a hazai kutatási eredményekhez hasonlóan megerösítést kapott az a tény, miszerint a beteg döntésekbe való bevonása $(\beta=0,459)$, illetve betegségével kapcsolatos tájékoztatása $(\beta=0,210)$ számottevően befolyásolja az elégedettséget, a fizikai környezet hatása pedig kevéssé releváns a páciensek elégedettségében a háziorvosi praxisokban $(\beta=-0,028)$. A kutatás újszerủ eredménye, hogy az orvos-beteg kommunikáció elemeinek meghatározó szerepe van a betegek elégedettségében, valamint pozitív irányú kapcsolat igazolódott az elégedettség és a lojalitás között $(ß=0,727)$.

\section{GYAKORLATI JAVASLATOK}

Kutatásunk eredményei a gyakorlatban alkalmazható minőségjavító tényezők új aspektusaira hívták fel a figyelmet. A háziorvosi ellátásban a hagyományosan jelentősnek vélt minőségi dimenziók (várakozási idő, fizikai környezet) mellett új tényezők jelentek meg releváns minőségértékelő szempontként (a beteg bevonása a döntésekbe, felvilágosítás, kommunikáció). Az eredmények alapján kijelölhetők a jövőbeli praxisfejlesztés fontosabb irányai: az orvos-beteg kommunikációnak, a beteg egyenrangú partnerként való kezelésének, a döntésekbe való bevonásnak az eddiginél jóval nagyobb szerepet kell kapnia a háziorvosi ellátásban.

Kulcsszavak: háziorvos, elégedettség, lojalitás, praxisfejlesztés, orvos-beteg kommunikáció

DOI: https://doi.org/10.15170/MM.2019.53.03.02 


\section{ELMÉLETI HÁTTÉR - SZAKIRODALMI ÁTTEKINTÉS}

\section{Mi a minőség, az elégedettség és a loja- litás? Hogyan definiáljuk?}

A minőség definiálása rendkívül bonyolult, hiszen a fogalom maga is sokrétủ, használata során pedig jelentése mindig a konkrét felhasználási környezettöl függ. Ki határozza meg azt, hogy mi az elfogadott és értelemszerú, mekkora a szerepe a minőségtényezők megitélésében a kínálónak és a fogyasztónak?

Marketingszempontból a minőség megítélése a fogyasztó kezében van; a fogyasztó véleménye azonban rendkívül szubjektív, és maga a minőség is megfoghatatlanná, plasztikussá válik. A korai kutatások szerint a fogyasztói minőség értékelése a szolgáltatásoknál az elvárás és a tapasztalat összhangján alapul. E megközelítések alapján az észlelt és az elvárt szolgáltatás összehasonlítása érzelmi reakciókat vált ki a fogyasztókból, amely az elégedettség vagy elégedetlenség érzését kelti a termékkel, szolgáltatással kapcsolatban (Parasuraman et al. 1985, Grönroos 1992, Fisk et al. 1993). Ahol az összehasonlíthatóság nyilvánvaló, a fogyasztót elégedettnek tekintik, de ez a legtöbb esetben nem elég a versenyelőnyhöz. Az újabb kutatások ugyanis azt találták, hogy a fogyasztó a szolgáltatás minőségét úgy értékeli, hogy összehasonlítja a jelen tapasztalatát azzal, amiről úgy hiszi, hogy a szolgáltatásnak olyannak kellene lennie. Ezek a megközelítések annyiban jelentenek újat, hogy az ideális szolgáltatás nyújtását nem tartották elegendőnek a tényleges előnyhöz, és arra figyelmeztettek, hogy egyre inkább szükség van a kiváló minőségre és arra, hogy felülmúljuk az elvárásokat, hogy örömet okozzunk a fogyasztónak, és ne csak kielégítsük az igényeit (Martensen et al. 2000, Zeithaml 2000).

A szolgáltatási teljesítményen belül megkülönböztethetö instrumentális és expresszív forma. Az instrumentális teljesítmény a folyamat technikai eredménye, az expresszív teljesítmény pedig a szolgáltatási folyamat során létrejövő eladó-vevő interakció pszichológiai aspektusát jelenti (Babakus \& Mangold 1992, Kenesei és Kolos 2014). A szolgáltatási minőséget a technikai minőség, a funkcionális minőség, valamint a szervezeti imázs határozza meg. A technikai minőség arra a kérdésre ad választ, hogy a fogyasztó mit a kap a szolgáltatás során, és ez a dimenzió objektíven, viszonylag jól megítélhető. A funkcionális minőséget a fogyasztók szubjektíven értékelik, azt mutatja, hogy a fogyasztó milyen módon részesül a szolgáltatásban, mi jellemzi a szolgáltatásteljesítményt (Ferguson et al. 1999, Fiala 2012).

A Parasuraman és társai (1988) által publikált öt minőségdimenzió tartalma az orvosi ellátás során a következők szerint értelmezhető:

1. Reagálási készség - az ellátás közvetlenül hozzáférhető, nem kell várakozni.

2. Biztonságérzet - a szolgáltatást nyújtó tudása, kompetenciája, hírneve valamiféle garanciát jelent a betegeknek, hogy a megfelelő minőségi színvonalú szolgáltatásban részesülnek.

3. Tárgyi elemek - a praxis környezete, rendelő és váró berendezése, nyomtatványok, írásos anyagok. 4. Megbízhatóság - időpontok, határidők betartása, pontos diagnózis és gyógyszerrendelés.

5. Empátiakészség - betegközpontú ellátás, odafigyelés, türelem, érzelmi támogatás.

Buyukozkan és szerzőtársai (2011) az egészségügyi szolgáltatások minőségét hat tényezővel mérték: anyagi erőforrások, reagálóképesség, megbízhatóság, bizalom, empátia és professzionalizmus. Kutatási eredményük alapján Törökországban az empátia a legfontosabb egészségügyi szolgáltatási minőségi tényező, de hasonlóan jelentős a profeszszionalizmus és a megbízhatóság. Weitzman (1995) (in: Kovner) szerint az egészségügyi ellátás minösége a következő három tényezővel határozható meg: az ápolás technikai szempontjai, az interperszonális kapcsolat az orvos és a beteg között, valamint az ellátás kényelme.

Magyarországon az 1990-es években született az egészségügyi ellátás minőségére vonatkozó hivatalos definíció, amely mindmáig széles körben használt. Ennek értelmében az egészségügyi szolgáltatás olyan értékítéletként fogható fel, amely az egészség megőrzésének és helyreállításának folyamatában részt vevők által megfogalmazott és elvárható igények megvalósulásának mértékét mutatja, az egyes tényezők tekintetében a jellemző mutató hozzárendelésével (Belicza - Zékány 1998). Gődény (2012) véleménye alapján a minőség az egészségügyben több szempont szerint ragadható meg:

1. Teljesítmény (amelyet befolyásol a technikai minőség, technológiai fejlettség)

2. A rendelkezésre álló erőforrások hatékony felhasználása

3. Kockázatmenedzsment (kockázat-értékelés, megelőzés)

4. Páciens elégedettsége

Az egészségügyi minőséget vizsgálók többségének véleménye szerint a minőség definiálása ebben a szférában azért is nehéz, mert az egészségügyi ellátás minősége az ügyfelek, 
a szakemberek, a vezetők, a döntéshozók és a finanszírozók számára eltérő (Naidu 2009, Mosadeghrad 2013, Lee \& Kim 2017).

Összefoglalóan azt mondhatjuk, hogy a minőség meghatározása az egészségügyben annak komplexitása és heterogenitása miatt szituációspecifikus, így definiálása is a vizsgált körülményektől függ.

A fogyasztói elégedettség kifejezi, hogy az adott szolgáltatás mennyiben felel meg a vevő elvárásainak. A szolgáltatásokkal való elégedettség tekinthető egy összehasonlító ítéletnek, érzelmi válasznak, amely a kapott szolgáltatás észlelt minőségének és a fogyasztó előzetes várakozásainak összehasonlítása nyomán alakul ki. Ennek az összevetésnek az eredménye egyes irodalmakban a fogyasztó által észlelt értékként jelenik meg. Emellett azonban nem csak az észlelt érték, vagy észlelt hasznosság a meghatározó, hanem az észlelt ráfordítások is, amelyek a szakirodalmi források nyomán elsősorban a megfelelőnek észlelt árakkal azonosíthatók. Az egyes szolgáltatásokkal való elégedettség így az észlelt szolgáltatásminőség, az előzetes elvárások, és a megfelelőnek észlelt árak nyomán létrejövő összehasonlító ítélet (Voss et al. 1998).

$\mathrm{Az}$ elégedetlen fogyasztó elpártolhat, mást keres, az elégedett fogyasztó nyitott, együttmüködő, a lojális fogyasztó pedig kitart a szolgáltatást nyújtó mellett. Az elégedettség pszichológiai állapot, öröm vagy csalódottság, amelyet a fogyasztó átél, amikor a termék vagy szolgáltatás észlelt teljesítményét és az előzetes várakozásait összehasonlítja. Az elégedettség a minőségről alkotott értékítélet alapján alakul ki.

Az elégedettség elérése marketingszempontból kiemelten fontos, mivel az elégedett fogyasztó gyakrabban és többet vásárol, magasabb árat hajlandó fizetni. Az elégedett fogyasztók hosszabb távon maradnak, nagyobb profitot hoznak (Veres 2009). Az elégedettség kialakulása az ún. diszkonfirmációs paradigmával írható le. A fogyasztó a termékkel vagy szolgáltatással szerzett tapasztalatait (a jelenlegi teljesítményt) egy standarddal, összehasonlítási alappal hasonlítja össze (elvárható teljesítménnyel). Amennyiben az összehasonlítás egyenlege pozitív, akkor a fogyasztó elégedett lesz.

Az elvárt teljesítmény lehet a fogyasztó fejében lévő, korábbi tapasztalat eredménye vagy egy leírt jogszabály, minőségügyi szabályozás. Az előzetes tapasztalatokat kiegészíthetik a személyi szükséglet motivációi, az informális kommunikáció, a szájreklám. A valóság észlelése és az észlelt helyzet értékelése a korábbi tapasztalatok tükrében történik. A tapasztalatokból elvárás lesz, amely a jövőbeni helyzetelemzést és értékelést befolyásolja (Hofmeister-Tóth és tsai. 2003).

$\mathrm{Az}$ elégedettség mérésének objektív és szubjektív formái is megkülönböztethetők. Az objektív jól mérhető, azonban az elégedettség mértékéről, az attitűdről nem nyújt információt. Ide soroljuk az újravásárlási rátát, illetve az elpártolás mértékét. A szubjektív felmérés esetén a fogyasztók közvetlen észlelései alapján mérjük fel a véleményüket a szolgáltatással kapcsolatban (Kenesei - Kolos 2014). Az elégedetlen fogyasztó elvárásai, igényei elmaradtak az észlelt szolgáltatásteljesítéstől, panasza van a szervezettel, a termékkel vagy szolgáltatással kapcsolatban.

A panaszok kezelése hiányában elpártolhat, negatív szájreklámmal csökkentheti az új fogyasztók megszerzésének esélyét, befolyást gyakorolhat a jelenlegi fogyasztókra is. Az elégedetlenség nem vezet automatikusan elpártoláshoz, függ a jogi, időbeli, földrajzi vagy egyéb korlátoktól. Az elégedetlenség hátterében álló okok feltárása és szervezeti kezelése lényeges. Leggyakrabban az elvárások és a teljesítés közötti differencia, a személyes jellemzők, a versenytársak kedvezőbb ajánlata, a speciális társadalmi normák miatt válnak a fogyasztók elégedetlenné.

Az elégedettség kialakulása az egészségügyi szolgáltatásoknál is pszichikai összehasonlítóértékelö folyamat eredményeként jön létre, amelynek során a beteg a szolgáltatás igénybevétele során összeveti a kapott szolgáltatást az elvárt vagy standard teljesítménnyel, a tapasztalatait a várakozásaival. Az összehasonlítási folyamat kimenetele az elégedettség, elégedetlenség vagy indifferens állapotok lehetnek (Illei 2011).

Az összteljesítmény megítélését befolyásolhatja a félelem vagy az öröm, ha túl van végre az ellátáson, akkor felszabadultabbnak érzi magát, pozitívabban értékelhet, elégedettebb lehet.

Az elégedettség módosulhat a folyamat során pozitív vagy negatív irányban, átmeneti vagy tartós elégedettséget eredményezve (pl. kényelmes, tiszta váró, rövid várakozási idő ellenére keveset foglalkoznak vele, kioktatják, nem hallgatják meg panaszait). Az elégedettséget tehát döntően az elvárások teljesülésének mértéke határozza meg. A személyzet kommunikációja, magatartása, a beteg számára nyújtott tájékoztatás, az adott információk mennyisége és minősége befolyásolhatják a elégedettséget, oldhatják a feszültséget, kétségeket, félelmet, ezáltal javítva a megítélést (Illei 2011, Hofmeister-Tóth és tsai 2003).

Az elégedetlenég kezelése fontos a további együttmüködés, kapcsolat, beteg compliance (az orvosi tanácsok követése, együttmüködés a 
terápiában), a lojalitás kiépítése szempontjából. A nem megfelelő panaszkezelés jelentékeny költségkihatással járhat, ide értve a panaszok kivizsgálásával, a megszüntetéssel kapcsolatos költségeket, az esetleges kártérítési perek kapcsán felmerült fizetési kötelezettségeket (Illei 2011).

Az ellátás kiválasztása (hol, melyik orvoshoz menjen) háziorvosi ellátás esetén relatíve korlátozott, inkább fekvőbeteg intézményekre jellemzö, hogy több információt gyüjtenek, számít az orvos gyakorlata, az intézmény megközelíthetősége, az ápolószemélyzet, a hotelszolgáltatások (egy vagy többágyas szobába fog kerülni). A háziorvosi körzet megválasztását döntően a területi, lakóhelyi odatartozás ténye determinálja, így a földrajzi korlátok miatt kényszerlojalitás alakulhat ki.

\section{A minőség, az elégedettség és a lojalitás mérése}

A szolgáltatások minőségének mérése többféle módon történhet attól függően, hogy az elvárásokat is mérjük-e, illetve súlyozzuk-e az eredményeket a fontossággal. A SERVQUAL-módszert az 1980-as évek második felében dolgozták ki és tették közzé (Parasuraman et al. 1988), ám a modellt több támadás is érte és a kritikák alapján továbbfejlesztették a módszert. Az eredeti SERVQUAL-modell alapján a minőség a teljesítmény és az elvárások közötti különbséget jelenti, a továbbfejlesztett modell pedig ezeket a különbségeket súlyozza azok fontossága szerint, azaz a fogyasztó számára fontosabb elemek nagyobb súllyal jelennek meg az értékelésben (minőség $=$ fontosság * teljesítményelvárások). A SERVQUAL módszer helyett más szerzők a mérésre az egyszerübb SERVPERF módszert javasolják, ahol a minőség egyenlő a teljesítménnyel (Parasuraman et al. 1988, Cronin \& Taylor 1992).

Az egészségügyi elemzők 1997 óta alkalmazzák a SERVQUAL modellt a betegek elégedettségének és lojalitásának mérésére, mivel a módszer segít az egészségügyi szolgáltatóknak a teljesítmény és az elvárások közötti különbségek azonosításában, és alkalmas arra, hogy a problémás minőségi dimenziókban a szolgáltatók javítani tudják a teljesítményt.

Vannak, akik a szolgáltatási elvárások (SEREXP - service expectations) valamint a szolgáltatási minőség észlelését (SERPER service perceptions) kutatták. A minőségi rések esetében megállapították, hogy a magán-egészségügyi SERPER magasabb, mint a SEREXP, azaz felülmúlja a teljesítmény az elvárásokat.
Andaleeb (2001) szerint nem szükséges a klasszikus 5 tényezőt (fizikai környezet, reagálási készség, biztonság, megbízhatóság, empátia) mérni, és azt javasolja, hogy ezeket a szolgáltatás specifikumainak megfelelően célszerü módosítani. Bangladesben vizsgálta a szolgáltatás minöségészlelését és a páciensek elégedettségét, ahol megváltoztatta az eredeti SEVQUAL tényezőket, és az elégedettséget más dimenziók felhasználásával is mérte, így az alábbiakkal: reagálási készség, biztonság, kommunikáció, fegyelem és hálapénz. Eredményei azt mutatják, hogy mind az öt dimenziónak jelentős hatása van a beteg elégedettségére. Manaf és Nooi (2009) a malajziai állami kórházi kutatásokban viszont éppen azt mutatták ki, hogy a klinikai (személyzet, kezelés és tájékoztatás) és fizikai (tisztaság, környezet és látogatási lehetőségek) tényezők is hatással vannak az elégedettségre. Azizan és Mohamed (2013) Malajziában végzett kutatási eredményei pedig azt mutatják, hogy a kórházi betegek elégedettségét az adminisztrációs szolgáltatás, az orvosi és ápolási ellátás jelentősen befolyásolják, míg a kórházi infrastruktúra és az interakció jelentéktelen kapcsolatot mutat az elégedettséggel. Más eredményekre jutottak mások, például Kanadában, megállapítva, hogy a betegek elégedettségét jelentős mértékben befolyásolják az ápolók, az orvosok és az információ.

Az elégedettség és a lojalitás nehezen választhatók el egymástól. A cégeknek, szolgáltatóknak végső során a lojalitás elérésére és fenntartására kell törekedniük (Veres 2009). A hosszú távon elégedett fogyasztókból lesznek a lojális fogyasztók, amely egy magasabb elismertségi és kötődési kategóriát jelent, hozzájárul az eredményességhez és a profitabilitáshoz (Kenesei - Kolos 2014). Lojális az a fogyasztó, aki:

- másoknak is ajánlja a terméket/szolgáltatást,

- a versenytársak csábítása ellenére kitart a termékünk, szolgáltatásunk mellett,

- amennyiben lehetősége volna rá újra a cégünket illetve a termékünket, szolgáltatásunkat választaná (Veres 2009).

A marketingkutatók hosszú ideig a lojalitás kulcsát a kiváló minőség biztosításában látták, amely növeli az elégedettséget, az elégedettség pedig hüséghez vezet (Fisk et al. 1993, Martensen et al. 2000). A minőség-elégedettség-lojalitás-jövedelmezőség szilárd logikáját azonban több tanulmány is cáfolja. Egyes kutatások szerint pusztán a kiváló minőség nem vezet elégedettséghez. Voss és tsai (1998) rámutatnak, hogy a témában végzett széleskörü elégedettség-kutatások zöme az (igénybevétel előtti) elvárásokra és az (igénybevétel után kialakult) elégedettségi szintre fókuszál. A szerzők 
megállapítják, hogy az empirikus kutatások tanulságai ellentmondanak egymásnak, és két pólus köré csoportosíthatóak a vélemények:

Anderson et al. (1994), Churchill és Surprenant (1982), Tse és Wilton (1988), Oliver (1999) pozitív kapcsolatot feltételeznek az elvárások és az elégedettség között;

Spreng és Olshavsky (1993) szerint pedig nincs szignifikáns kapcsolat az elvárások és az elégedettség között.

A kérdéskört vizsgáló kutatások eredményeit összefoglalva Zeithaml (2000) rámutat arra, hogy mind a pozitív, mind a negatív összefüggésekre vonatkozóan böségesen találunk bizonyítékokat. Később mások arra is figyelmeztettek, hogy az elégedettség nem vezet feltétlenül lojalitáshoz (Jones \& Sasser 1995, Reichheld 1996, Stewart 1997), és több hazai kutatás is felhívta a figyelmet arra, hogy sem a minőség, sem a lojalitás mérései nem igazolják az alkalmazott modellek általánosíthatóságát (Hetesi - Rekettye 2001, Hetesi 2003).

A kutatásokban használt modellek azonban nagyon változatos képet mutatnak, és az elégedettség/lojalitás kutatásoknak mindig igazodnia kell a vizsgálni kívánt ágazat, szolgáltatás jellemzőihez, az ügyfélkör speciális igényeihez is (Veres és tsai 2016).

Az egészségügyi ellátásra specifikusan kifejlesztett elégedettség-lojalitás modellt a szakirodalomban nem találtunk. Az egészségügyben általában kényszerlojalitás jellemző, földrajzilag és szakmai szempontból behatárolt a szolgáltatás igénybe vehetősége, elégedetlenség esetén az állami egészségügyi szolgáltatásoknál korlátozott a váltási lehetőség.

A háziorvosi ellátásban ez kevésbé érvényesül, mivel bizonyos keretek között a jogszabályok lehetőséget adnak a betegnek az orvosa megváltoztatására. A területi ellátási kötelezettség alapján a háziorvos köteles ellátni az ellátási területén belül lakó, hozzá bejelentkezett, az általa elfogadott biztosítottakat. A háziorvosi tevékenységről is rendelkező jogszabály (4/2000. (II. 25.) EüM rendelet) alapján a páciensek számára évente egy alkalommal indokolás nélkül, ezen túlmenően indokolt esetben (tartózkodási hely megváltozása, a választott háziorvos felkeresése akadályba ütközik) lehet átjelentkezni másik háziorvoshoz. A háziorvosi kényszerlojalitásnál kényelmi és megszokási szempontok is érvényesülhetnek a körzetben maradásban.

A kutatásunkban a háziorvosi ellátásra vonatkozóan egy új modellt alkottunk, amely a betegelégedettséget potenciálisan befolyásoló tényezők szerepét és az elégedettség-lojalitás összefüggését vizsgálja.

\section{EMPIRIKUS KUTATÁS}

\section{A kutatás szakirodalmi megalapozása}

Vizsgálatunkban az általánosan használt szolgáltatásminőség paramétereket próbáltuk adaptálni speciálisan az egészségügyi szolgáltatásokra, és hipotéziseinket ennek alapján fogalmaztuk meg.

Az ellátás meghatározó elemei a szolgáltatások megfoghatatlan jellegéből eredően a fizikai környezet és az ellátó személyzet (megjelenése, magatartása). A betegek kellő szaktudás hiányában az orvos, illetve a frontvonalban dolgozó személyzet magatartásából, a váró és rendelő berendezéséből következtetnek az elégedettségüket befolyásoló szolgáltatás-minőségre. Az utazási távolság, várakozási idő, fizikai környezet, személyzet interperszonális jártassága/ügyessége azok, amelyeket a páciens is meg tud ítélni és érzékel az ellátás során (Grytten et al. 2009). Az orvos kommunikációját, a megfelelő információátadást, a kezelés kimenetelét a betegek fontosnak tartják a háziorvosuk értékelésekor (Bowling et al. 2013, Paddison et al. 2015).

A szakirodalmi források áttekintése alapján kutatásunkban a várakozási időnek, a betegek döntésekbe történő bevonásának, a háziorvos felkészültségének, a fizikai környezetnek, a betegek felvilágosításának a betegelégedettségre gyakorolt hatását kívánjuk mérni.

Hazai és nemzetközi betegelégedettségi felmérésekben is szerepel a várakozási idő, mint az ellátás minőségének egy igen lényeges, mérhető eleme (Grytten et al. 2009, Szatmári és tsai 2010). A betegeknek sokszor hosszú időt (egy óránál is többet) kell várniuk, míg sorra kerülnek, amely befolyásolhatja az elégedettségüket. Ez alapján megfogalmazhatjuk az első hipotézisünket:

H1. A várakozási idő megítélése hatást gyakorol az ellátás egészével való elégedettségre.

Kanadai kutatók az orvos-beteg kapcsolatban a személyes adottságok (empátia, barátságosság, törődés, meggyőzés, együttérzés) szerepét hangsúlyozták. Eredményeik szerint az interperszonális kapcsolati jellemzők szignifikáns hatást gyakorolnak az egészségügyi ellátással való elégedettségre (Boquuiren et al. 2015). Az orvosi ellátás során a beteget a lehető legteljesebb mértékben befolyásolhatja az orvosi kommunikáció, ennek személyre szabottsága, a betegségéről adott felvilágosítás, a kérdésekre adott válaszok, a beteg bevonása a folyamatba.

A hatékony kommunikáció hozzájárul az észlelt kockázat csökkentéséhez, növeli a szolgáltatásminőséget, a betegek elégedettségét, a kártérítési perek számának csökkentéséhez vezethet (Vajda 
és tsai 2012). Ezen állítás igazolására a második hipotézisünk:

$H 2$. A betegeknek a betegségükkel kapcsolatban nyújtott háziorvosi felvilágosítás hatást gyakorol a háziorvos összteljesítményének megítélésére.

Az ellátás során paternalista stílust tapasztalók 51\%-a igényelne más kommunikációs stílust, ezen betegek szignifikánsan alacsonyabb arányban észlelik kiválónak a minőséget, összehasonlítva azokkal, akik közös döntést jelöltek meg. Összességében a paternalista stílust észlelők az ellátás minőségének dimenzióival kevésbé elégedettek, szignifikánsan kevesebben érezték a kitünő gondoskodást a háziorvos részéről. A háziorvosi-beteg kapcsolat kimenetei az együttműködést alapvetően befolyásolják, hozzájárulva a beteg egészségi állapotának javulásához (Kincsesné Vajda 2013). Ezen megfigyeléshez rendeljük a harmadik hipotézisünket:

H3. A beteg bevonása az egészségi állapotával kapcsolatos döntésekbe befolyásolja a háziorvosi ellátással való elégedettségét.

Mint azt Grytten és társai (2009) is igazolták, a fizikai környezet, a váró és rendelő berendezése, a várakozási idő, a frontvonalban dolgozó személyzet magatartása, kommunikációja fontos szerepet játszik betegek egészségügyi szolgáltatás minőségéről alkotott véleményének formálásában. Szakmai ismeretek hiányában a betegek a fizikai környezet elemeit a szolgáltatás minősége jelzőjeként tekinthetik. Ezen feltételezéshez fogalmazzuk meg a negyedik hipotézisünket:

H4. A háziorvosi ellátás fizikai környezetének megítélése befolyásolja az ellátás összességével való elégedettséget.
Az orvosi ellátás szakmai megfelelőségét alapvetően meghatározza a háziorvos meglévő tudása, felkészültsége (Mpinga \& Chastonay 2011, Simon 2010), amelyet a beteg az információs aszimmetria tükrében érzékel és összevetve elvárásaival véleményt formál. Ennek megfelelően a hipotézisünk:

H5. A háziorvos tudása, felkészültsége hatást gyakorol az ellátás egészével kapcsolatos elégedettségre.

Az elégedettség hosszabb távon egy szorosabb kapcsolathoz, kötődéshez, a lojalitáshoz vezethet. A lojalitás az elégedettséggel összefüggő fogalom, magatartási és érzelmi dimenziók szerint is megközelíthető, általában pozitív attitüddel, a termék/ szolgáltatás újrafogyasztásával párosul. A fogyasztó akár nagyobb erőfeszítéseket is képes megtenni a termék/szolgáltatás megszerzéséért (Dick \& Basu 1994, Oliver 1999).

A lojális betegre jellemző, hogy az általa kedvelt orvost másnak is ajánlja, kedvezőbb ajánlat(ok) ellenére a praxisban marad, valamint újra az adott orvost választaná, ha lehetősége lenne rá (Macstravic 1994). A vizsgálatunkban a lojalitásra vonatkozóan négy hipotézist fogalmazhatunk meg:

H6. A háziorvos szolgáltatásaival való összelégedettség és a lojalitás között kapcsolat van.

H7. A páciensek lojalitása befolyásolja a háziorvos melletti kitartást (újra a jelenlegi orvost választanák).

H8. A lojalitás befolyásolja az orvos továbbajánlását másoknak.

H9. A lojalitás hatást gyakorol arra, hogy a páciens a versenytársak kedvezőbb ajánlata ellenére sem váltana háziorvost.

A szakirodalmi eredmények és hipotéziseink alapján az alábbi modellt alkottuk meg (1. ábra):

\section{1. ábra: Az elégedettségre és lojalitásra vonatkozó hipotéziseink}

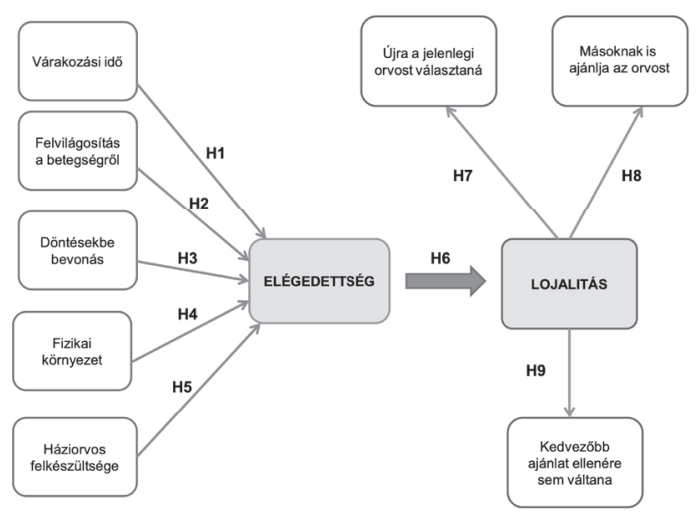

Forrás: saját szerkesztés 


\section{Vizsgálati módszer és eredmények}

Hipotéziseink és a modell tesztelésére kvantitatív személyes kérdőíves kutatást alkalmaztunk. Kutatásunk előkészítésekor a SERVQUAL (Parasuraman et al. 1991) módszer használata mellett döntöttünk, elfogadva alapfeltevéseit, ugyanakkor jelentősen módosítva a skálákat annak érdekében, hogy alkalmas legyen az egészségügyi (háziorvosi) ellátással kapcsolatos értékítélet megragadására. A kérdőív szerkesztésének alapjául nemzetközileg alkalmazott, a betegelégedettséget az alapellátásban felmérő norvég EUROPEP (European Project on Patient Evaluation of General Practice) kérdőív (Bjertnaes et al. 2011), valamint ennek módosított, rövidebb változata szolgált (Gavran et al. 2013). A kérdőív összeállításához a hazai szakirodalomban fellelhető, hasonló vizsgálatok adatfelvételében használt kérdőíveket is figyelembe vettük (Kertész és tsai 2006, Szatmári 2009, Bánfai és tsai 2015).

A vizsgálatban alapsokaságaként Szeged és környéke háziorvosi rendelöiben a 18 év feletti személyeket céloztuk meg.

A minta kiválasztása kétféle módszerrel történt. Egyrészt a vizsgálat célja miatt (elégedettség-lojalitás) arra koncentráltunk, hogy olyan páciensek kerüljenek a mintába, akik gyakran látogatják a háziorvost, így egy szegedi háziorvosi rendelőben az adatfelvételi időszakban megjelenő betegek megkérdezése történt a váróhelyiségben a vizsgálatot megelőzően, másrészt hólabda módszert alkalmaztunk Szeged, Makó és Kecskemét városokban. Itt az első válaszadók olyan ismerősök voltak, akik az adott városban a háziorvos körzetének páciensei, majd az általuk javasolt - a háziorvost gyakran látogató - további személyek felkeresése és megkérdezése történt. Mintánk tehát nem tekinthető reprezentatívnak, hiszen az alapsokaságból azokra koncentráltunk, akik kompetensek az elégedettség megítélésében.

A minta jellemzése leíró statisztikai mutatókkal történt, a változók közötti összefüggéseket matematikai statisztikai eljárásokkal igazoltuk. A leíró statisztikával elhelyezkedési (átlag) és szóródási mutatókat (szórást, szórásnégyzetet) számítottunk. Egyszempontos variancia-analízissel (ANOVA) a metrikus, intervallumskálán mért függő változók és a nem metrikus, nominális- vagy ordinális skálán mért független változók közötti kapcsolat jelenlétét és erősségét vizsgáltuk.

A látens változók és a manifeszt változók közötti kapcsolatok feltárására a strukturális egyenletek modelljét (SEM) használtuk, amely lehetővé teszi a szimultán faktor és regresszióanalízist. Ezen belül, tekintettel a modellünk komplexitására, az ordinális skálára és a mintánk elemszámára, a variancia-alapú (partial least squares=parciális legkisebb négyzetek) technikát választottuk (PLS-útelemzés) (Haenlein \& Kaplan 2004, Hair et al. 2011, Kazár 2014). A PLS-útelemzést a SmartPLS számítógépes program segítségével végeztük (https://www.smartpls.com/).

A látens változók körében a függetleneket exogén, a függőkket endogén változónak tekintjük. Az exogén változók mindig magyarázó változók, az endogén változók lehetnek célváltozók és magyarázó változók is (pl. elégedettség).

A látens változók közötti közvetlen kapcsolat elemzése a standardizált útegyütthatókkal valósítható meg. Modellünkben vizsgáltuk a fizikai környezet, a várakozási idő, a döntésekbe bevonás, a háziorvos felkészültségének, a felvilágosítás a betegségről látens változók hatását az elégedettségre, valamint elemeztük az elégedettség és lojalitás közötti kapcsolatot.

A modellben exogén változóként szerepel a fizikai környezet, a várakozási idő, a döntésekbe bevonás, a háziorvos felkészültségének, a felvilágosítás a betegségröl. Endogén változó az elégedettség, a lojalitás, a „másoknak is ajánlja az orvosát”, az „újra a jelenlegi orvost választaná” és a „kedvezőbb ajánlat ellenére sem váltana háziorvost" kategóriák.

A látens változók (konstrukciók) megbízhatóságát, a belső konzisztenciát a Cronbach-féle $\alpha$ mutatóval mértük, amelynél 0,7-et vettünk alsó határértéknek (Hair et al. 2009).

A konvergencia-érvényesség tesztelésére az átlagos kivonatolt varianciát (average variance extracted $=\mathrm{AVE}$, elfogadhatóság 0,5 felett), valamint az összetétel megbízhatósági mutatót (composite reliability $=\mathrm{CR}$, elfogadhatóság 0,7 felett). (Hair et al. 2009; Kovács - Bodnár, 2016).

A statisztikai vizsgálathoz IBM SPSS Statistics 24 programot is alkalmaztunk.

\section{A minta összetétele}

A kérdőíves adatfelvétel összesen 120 fő megkérdezésével történt, 30 fö válaszolt a háziorvosi rendelöben végzett, valamint 90 fö a rendelőn kívüli megkérdezéskor. A háziorvosi körzetben a megkérdezettek közel $80 \%$-a vállalta a részvételt.

A felmérésben résztvevő személyek átlagéletkora 50 év volt (19-92 év), legtöbben (44\%) a 45-64 éves korosztályba tartoztak. A nők felülreprezentáltak a mintában $(70 \%)$, iskolai végzettség szerint pedig a középfokú végzettséggel rendel- 
kezők domináltak. A megkérdezettek $87 \%$-a több mint két éve jár háziorvosához, 51\%-ban területi ellátási kötelezettség miatt. Viszonylag magas azon egyének aránya is (46\%), akik ajánlás útján, ismerősi vagy családi körből hallott kedvező tapasztalatok miatt választották az adott háziorvost.

\section{EREDMÉNYEK}

Az elégedettséghez kapcsolódó hat vizsgált konstrukció közül a fizikai környezet és a lojalitás kivételével mindegyikre teljesült a megbízhatóságra, belső konzisztenciára vonatkozó feltétel $(\alpha>0,7)$.

A fizikai környezet és a lojalitás kivételével valamennyi látens változó teljesíti a konvergencia- érvényességi kritériumokat is (AVE> 0,5 és $\mathrm{CR}>0,7)$.

A betegek $80 \%$-a összességében elégedett vagy nagyon elégedett volt a háziorvosával, az ötfokozatú Likert-skála szerint átlagosan 4,27-re értékelték a teljesítményüket. A betegek az ellátással kapcsolatos tényezők közül leginkább a háziorvosuk tudásával és felkészültségével voltak elégedettek $(4,55)$ illetve az orvos érdeklődését a panaszok iránt, valamint a vizsgálatot is magasra értékelték $(4,45)$. A háziorvos által a betegre fordított idővel is alapvetően meg voltak elégedve $(4,37)$, azonban a betegségükkel kapcsolatos döntésekbe véleményük szerint már kevésbé vonták be őket $(3,90)$. Legkevésbé a háziorvos által felajánlott életmódtanácsokkal, megelőző szolgáltatásokkal voltak elégedettek $(3,33)$. A praxis-szervezésre vonatkozó tényezők közül legnagyobb elégedettséget a körzet telefonos elérhetőségével $(4,56)$, a háziorvos elérhetőségével $(4,32)$, a kapott időponttal $(4,34)$ kapcsolatosan mértük. A betegek egyértelműen a várakozási idő hosszúságával voltak legkevésbé megelégedve $(3,27)$. A látens és manifeszt változók összefüggéseinek vizsgálatakor kapott eredményeket az 1 . táblázat szemlélteti.

\section{1. táblázat: A kutatásunkban vizsgált látens változók és indikátoraik statisztikai jellemzői}

\begin{tabular}{|c|c|c|c|c|}
\hline $\begin{array}{l}\text { Látens változó } \\
\text { (Cronbach-Alfa, } \\
\text { AVE, CR) }\end{array}$ & Item & Faktorsúly & Átlag & Szórás \\
\hline \multirow{7}{*}{$\begin{array}{l}\text { Döntésekbe } \\
\text { bevonás } \\
(\alpha=0,933, \\
A V E=0,714, \\
C R=0,947)\end{array}$} & A háziorvos érdeklődik a problémája iránt. & 0,933 & 4,27 & 1,12 \\
\hline & $\begin{array}{l}\text { A háziorvos bevonja a betegségével kapcsolatos } \\
\text { döntésekbe. }\end{array}$ & 0,836 & 3,90 & 1,15 \\
\hline & $\begin{array}{l}\text { A háziorvos mindig elegendő időt fordít } \\
\text { problémájára. }\end{array}$ & 0,869 & 4,27 & 1,04 \\
\hline & A háziorvos kikérdezi és megvizsgálja. & 0,800 & 4,45 & 0,93 \\
\hline & $\begin{array}{l}\text { A háziorvos segítséget nyújt az érzelmi problé- } \\
\text { mákkal történő megküzdéshez. }\end{array}$ & 0,770 & 3,50 & 1,40 \\
\hline & A háziorvos figyelembe veszi a beteg érdekeit. & 0,846 & 4,33 & 1,02 \\
\hline & $\begin{array}{l}\text { Teljesen elégedett az ellátás során kapott } \\
\text { információkkal. }\end{array}$ & 0,880 & 4,14 & 0,85 \\
\hline \multirow{5}{*}{$\begin{array}{l}\text { Felvilágosítás a } \\
\text { betegségről } \\
(\alpha=0,921, \\
\mathrm{AVE}=0,761, \\
\mathrm{CR}=0,941)\end{array}$} & $\begin{array}{l}\text { A háziorvos felajánl megelőző szolgáltatásokat és } \\
\text { életmód tanácsot ad. }\end{array}$ & 0,865 & 3,33 & 1,43 \\
\hline & $\begin{array}{l}\text { A háziorvos érthetően elmagyarázza a vizsgálatok } \\
\text { és kezelések célját. }\end{array}$ & 0,914 & 3,90 & 1,15 \\
\hline & $\begin{array}{l}\text { A háziorvos mindig felvilágosítja a betegségéről } \\
\text { és tünetekről. }\end{array}$ & 0,911 & 4,00 & 1,08 \\
\hline & $\begin{array}{l}\text { A tanácsok és utasítások követésének fontossá- } \\
\text { gára felhívja a figyelmet. }\end{array}$ & 0,824 & 4,06 & 1,07 \\
\hline & $\begin{array}{l}\text { A háziorvos felkészíti, hogy mi történik a } \\
\text { szakrendelésen. }\end{array}$ & 0,846 & 3,38 & 1,36 \\
\hline
\end{tabular}


1. táblázat folytatása

\begin{tabular}{|c|c|c|c|c|}
\hline $\begin{array}{l}\text { Látens változó } \\
\text { (Cronbach-Alfa, } \\
\text { AVE, CR) }\end{array}$ & Item & Faktorsúly & Átlag & Szórás \\
\hline \multirow{5}{*}{$\begin{array}{l}\text { Fizikai } \\
\text { környezet } \\
(\alpha=0,641, \\
\mathrm{AVE}=0,444, \\
\mathrm{CR}=0,763)\end{array}$} & A rendelő személyzete mindig nagyon segítőkész. & 0,931 & 4,14 & 0,95 \\
\hline & A rendelő személyzete bizalomkeltő. & 0,899 & 4,24 & 0,86 \\
\hline & $\begin{array}{l}\text { Teljesen elégedett a körzet telefonos } \\
\text { elérhetőségével. }\end{array}$ & 0,593 & 4,56 & 0,79 \\
\hline & $\begin{array}{l}\text { A rendelő megközelíthetőségével, a parkolással } \\
\text { elégedett. }\end{array}$ & 0,409 & 4,38 & 0,98 \\
\hline & Váró és rendelő tisztaságával elégedett. & 0,161 & 4,00 & 0,83 \\
\hline \multirow{2}{*}{$\begin{array}{l}\text { Háziorvos felké- } \\
\text { szültsége } \\
(\alpha=0,901, \\
\mathrm{AVE}=0,910 \\
\mathrm{CR}=0,953)\end{array}$} & A háziorvos alapos az ellátás során. & 0,957 & 4,36 & 0,94 \\
\hline & A háziorvos tudása és felkészültsége megfelelő. & 0,951 & 4,55 & 0,78 \\
\hline \multirow{5}{*}{$\begin{array}{l}\text { Várakozási idő } \\
(\alpha=0,763, \\
\mathrm{AVE}=0,501, \\
\mathrm{CR}=0,831)\end{array}$} & A háziorvos elegendő időt fordít a betegre. & 0,819 & 4,37 & 1,04 \\
\hline & A háziorvos mindig elérhető, amikor szükséges. & 0,818 & 4,32 & 0,98 \\
\hline & Teljesen elégedett a kapott időponttal. & 0,626 & 4,34 & 1,13 \\
\hline & Rendelési idő hosszúságával elégedett. & 0,659 & 4,17 & 1,05 \\
\hline & Várakozási idővel teljes mértékben elégedett. & 0,581 & 3,27 & 1,00 \\
\hline \multirow{3}{*}{$\begin{array}{l}\text { Lojalitás } \\
(\alpha=-0,659, \\
\mathrm{AVE}=0,821, \\
\mathrm{CR}=0,672)\end{array}$} & Másoknak is ajánlja az orvosát. & 0,937 & 4,29 & 1,13 \\
\hline & Újra a jelenlegi orvost választaná. & 0,944 & 4,15 & 1,30 \\
\hline & Kedvezőbb ajánlat ellenére sem váltana. & 0,833 & 2,11 & 1,51 \\
\hline
\end{tabular}

Forrás: saját szerkesztés

Az életkorcsoportok közül a 45-64 évesek voltak leginkább megelégedve a háziorvossal $(4,45)$. A nemek között alig volt különbség, közel azonos mértékben voltak elégedettek a férfiak $(4,22)$ és a nők $(4,28)$ a háziorvossal. Az adatfelvétel helyszíne szerint a háziorvosi körzetben megkérdezettek összességében kedvezőbben ítélték meg az ellátás egészét $(4,80)$, mint a rendelőn kívül nyilatkozó személyek $(4,09)$.

A vizsgálatra szánt idő növekedésével a betegek egyre inkább úgy érzik, hogy felvilágosították őket a betegségükkel kapcsolatban. Akikre az orvos 10 percnél kevesebb időt szánt a felvilágosítást kevésbé nagyra értékelték $(3,38)$, mint azok, akiknél ez 10 percnél is több volt $(4,56)$. A két tényező között összefüggés igazolható (Eta=0,470). A betegre szánt idő növekedésével a háziorvosi ellátás alaposságával is sokkal elégedettebbek voltak azok, akik 10 percnél többet töltöttek a rendelőben $(4,71)$ összehasonlítva azon páciensekkel, akik 10 percnél kevesebbet $(3,77)(\mathrm{Eta}=0,444)$.

$\mathrm{Az}$ elégedettséggel kapcsolatos hipotéziseink statisztikai tesztelését követően a PLS útelemzéssel kapott standardizált útegyütthatók alapján a következő megállapítások tehetők:
- $\quad$ az elégedettség magyarázó ereje,

- az elégedettségre a hozzá kapcsolódó dimenziók közül legnagyobb hatást a beteg döntésekbe bevonása fejti ki $(\beta=0,459)$,

- $\quad$ ezt követi a beteg felvilágosítás a betegségröl $(\beta=0,210)$,

- a háziorvos felkészültsége csak a harmadik helyen szerepel az útegyütthatók alapján $(\beta=0,193)$,

- a várakozási idő útegyütthatója csupán $\beta=0,106$,

- fizikai környezet és az elégedettség között nincs szignifikáns statisztikai összefüggés $(ß=-0,028)$.

A lojalitással kapcsolatos feltételezéseink tesztelése során a következö összefüggést kaptuk:

- a lojalitáshoz köthető változók közül a legnagyobb hatás az orvos újraválasztásával összefüggésben igazolható $(\beta=0,944)$,

- a háziorvos másnak történő ajánlása $(ß=0,937)$, illetve a kedvező ajánlat ellenére történő maradás (váltás elutasítása) $(ß=0,833)$ követnek. 
Az ellátással való teljes elégedettség és a lojalitás, mint endogén változók között pozitív irányú, lineáris kapcsolatot igazoltunk $(\beta=0,727)$.

Az elégedettség $(0,780)$ és a lojalitás $(0,529)$ determinációs együtthatói alapján a magyarázó erő jónak minősíthető, a változók között lineáris függvényszerü kapcsolatot találtunk.

Az útegyütthatók szorzata alapján a lojalitásra az elégedettségen keresztül közvetetten legerősebb hatást a beteg döntésekbe történő bevonása gyakorolja $(\beta=0,334)$, amelyet a felvilágosító tevékenység $(\beta=0,153)$, valamint a háziorvosi felkészültség $(\beta=0,141)$ követnek. A fizikai környezet a lojalitásra még közvetetten sem gyakorol hatást $(\beta=-0,020)$. A manifeszt és látens változók közötti indirekt hatást a 2. táblázat foglalja össze.

\section{2. táblázat: Az exogén változók hatása az endogén változókra}

\begin{tabular}{|l|r|}
\hline Specifikus indirekt hatások & Teljes indirekt hatások \\
\hline Döntésekbe bevonás -> Elégedettség -> Lojalitás & 0,334 \\
\hline Felvilágosítás a betegségröl -> Elégedettség -> Lojalitás & 0,153 \\
\hline Fizikai környezet -> Elégedettség -> Lojalitás & $-0,020$ \\
\hline Háziorvos felkészültsége -> Elégedettség -> Lojalitás & 0,141 \\
\hline Várakozási idő -> Elégedettség -> Lojalitás & 0,077 \\
\hline
\end{tabular}

Forrás: saját szerkesztés

Az elégedettségre ható tényezőket és az elégedettség-lojalitás kapcsolatát a 2. ábra szemlélteti.

\section{2. ábra: A betegek elégedettségének és lojalitásának meghatározó tényezői}

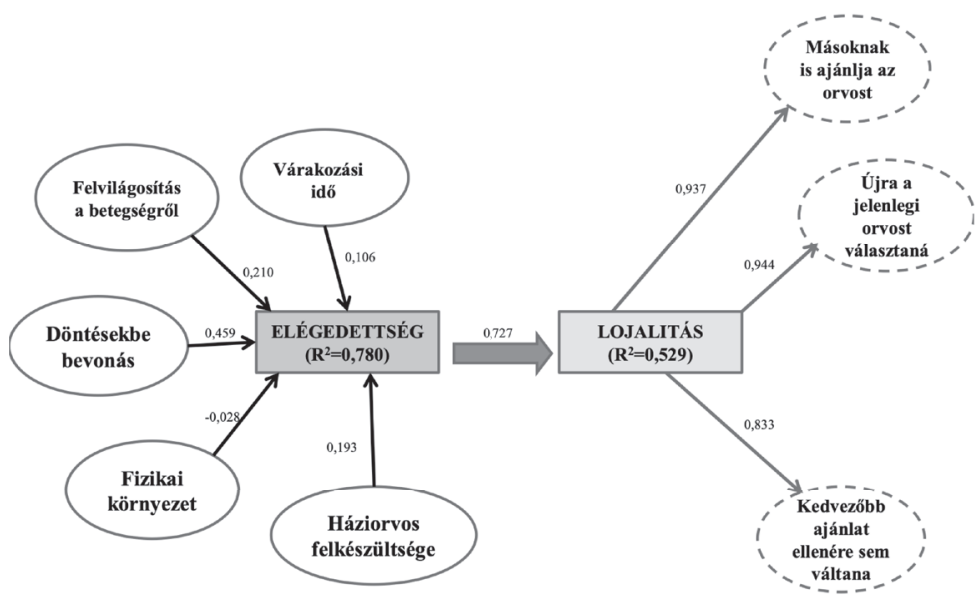

Forrás: saját szerkesztés 


\section{DISZKUSSZIÓ}

A kutatásunkban a megkérdezettek $80 \%$-a elégedett vagy nagyon elégedett háziorvosával. A háziorvosi ellátással való elégedettség országos szintủ felmérése során a megkérdezettek 83,7\%-a, a körzeti nővérrel 90,6\%-a elégedett vagy nagyon elégedett volt. A betegek $85 \%$-a nem tervez orvost váltani (Kertész és tsai 2006). Az Európai Lakossági Egészségfelmérés 2014-es eredményei hasonlóan magas elégedettségi szintet $(86 \%)$ mutattak a háziorvosi ellátásra vonatkozóan. 2009 óta a háziorvosi ellátás megítélése lényegében nem változott, általában a páciensek ,jó" osztályzatot adtak (KSH 2015). Érdekes megfigyelés, hogy azon országokban (pl. Portugália, Dánia, Norvégia, Hollandia), ahol a háziorvos „kapuőri” szerepe erőteljesen érvényesül a betegek általános elégedettsége alacsonyabb, mint ahol a közvetlen hozzáférés biztosított a különböző ellátási formákhoz. A különböző ellátási formákhoz való közvetlen hozzáférés esetén a háziorvosnak több specializált „versenytársa” van jelen, ezért jobban igyekszik a beteg érdekében járni, figyelembe venni a kívánságait, elvárásait, amely fokozhatja az elégedettséget (Kroneman et al. 2006)

Finn szerzők szerint az alapellátásban az elégedetlenség leggyakoribb okai: a konzultáció időtartama, döntésekbe való bevonás hiánya, a személyes életkörülményekkel való csökkent foglalkozás, a hosszú előjegyzés és várakozási idő (Säilä et al. 2008).

$\mathrm{Az}$ Országos Alapellátási Intézet által koordinált, 2190 fö bevonásával végzett pilot studyban a kérdések az betegek egészség-magatartásán és az orvos-beteg kapcsolaton kívül a várakozási időre is vonatkoztak (Szatmári 2009). A felnőtt betegek $25 \%$-a 20 percen belül bejutott az orvosához, míg 10\%-uknak 60 percnél is többet kellett várnia, amíg beszólították.

Egy szintén magyarországi, nagyobb elemszámú (5007 fös) vizsgálatban a nem előjegyzett felnőtt betegeknél is gyakori volt a 60-70 perces vagy azon túli várakozási idő (Szatmári és tsai 2010). Noha saját felmérésünkben a 60 percen túli várakozás idő viszonylag magas $(17 \%)$ arányát találtuk, ennek ellenére a várakozási idő kedvezőtlen megítélése csupán kis mértékben gyakorolt befolyást a háziorvossal való elégedettségre.

Különösen a professzionális szolgáltatásoknál a szolgáltatás minőségének megítélésében, az elégedettség kialakulásában a megfogható tárgyi elemeknek, a fizikai környezetnek kiemelt szerepe van. A fizikai környezettel, a rendelő berendezé- sével, tisztaságával felmérésünkben a válaszolók $70 \%$-a elégedett vagy teljesen elégedett volt, más kutatásban hasonlóan magas (85\%-os) arányt találtak (Szatmári és tsai 2010). Kutatási eredményeink azt jelzik, hogy a háziorvosi ellátással kapcsolatos elégedettséget leginkább az orvos-beteg kommunikáció elemei (felvilágosítás, döntésekbe bevonás) határozzák meg.

A hazai kutatási eredménykehez képest újszerü eredmény a felmérésünkben, hogy a fizikai környezet nem játszik releváns szerepet a betegelégedettség kialakulásában. Ez az eredmény kétféleképpen is értelmezhető: egyrészt az orvos személyisége, a szakmai munka színvonala kompenzálhatja a kedvezőtlen megítélést, másrészt az beteg-fizikai környezet interakció nem olyan szoros és tartós, mint egy fekvőbeteg-ellátást nyújtó egészségügyi szolgáltató esetén.

\section{ÖSSZEGZÉS}

A betegelégedettség értékes indikátor az egészségügyi szakdolgozók és döntéshozók számára, lehetővé téve a jobb stratégiák és irányítási-szervezési módszerek kimunkálását, a képzési-fejlesztési irányok meghatározását, az erőforrások optimális allokálását.

A saját felmérésünk és a szakirodalmi adatok alapján is elmondható, hogy a betegek zöme elégedett vagy nagyon elégedett a háziorvosa által nyújtott szolgáltatással. Ennek a minőségi színvonalnak a fenntartásra, javítása fontos egészségpolitikai feladat a jövőben. A XXI. század egészségügyében a betegbiztonság az egyik legfontosabb kérdés, amelynek egyik pillére a kiváló minőségü szolgáltatás. A minőség megfelelő biztosításához strukturális, humán erőforrás és finanszírozási háttér szükséges. Az ellátórendszer átalakítása a gazdasági-társadalmi kihívásoknak megfelelően nem halasztható tovább.

A betegelégedettségre ható, a beteg által is jól érzékelhető és megitélhető - Parasuraman által is leírt - minőségi dimenziók közül legfontosabb az empátia. Az empatikus, a betegre odafigyelő, jól kommunikáló, a beteget a döntésekbe bevonó, türelmes orvos és asszisztens személyzet az ellátás egyéb területein esetlegesen észlelt szolgáltatásminőség hiányosságokat jól kompenzálhatja.

A felmérésünk korlátját jelentheti, hogy a vizsgálat jellegéből következően (adatvédelmi előírások, szervezési nehézségek, adathiány), nem lehetett biztosítani az alapsokaság szociodemográfiai jellemzők szerinti megoszlását, így a minta nem tekinthető reprezentatívnak. Limitációt jelent 
továbbá a statisztikailag alacsony esetszám, a területileg korlátolt adatbázis. Mindazonáltal a jogszabályi elöírások és feltételrendszer behatárolják az egy-egy háziorvosi körzet által nyújtható szolgáltatások körét, ebben nincsenek országon belüli jelentős eltérések. A kapott eredményeinket ezek alapján használhatónak és jelzésértékűnek tekinthetjük egy szűkebb régióra fókuszálva is.

A hatékony, mindkét fél elégedettségét eredményező ellátás megvalósításához, a jövőbeli fejlesztések irányának meghatározásához azonban nem csak a betegek, hanem a szolgáltatást nyújtó egészségügyi dolgozók véleményének megismerésére is törekednünk kell. Ehhez további, rendszeres kvantitatív és kvalitatív elégedettségi vizsgálatok szükségesek a tendenciák megfigyelésével és az eredmények adekvát visszacsatolásával.

\section{HIVATKOZÁSOK}

Andaleeb, S. S. (2001), "Service quality perceptions and patient satisfaction: a study of hospitals in a developing country", Social Science \& Medicine, 52 9, 1359-70 DOI: https://doi. org/10.1016/S0277-9536(00)00235-5

Anderson, E. W., Fornell, C. and Lehmann D. R. (1994), "Customer Satisfaction, Market Share, and Profitability", Journal of Marketing, 58 3, 53-66 DOI: $10.2307 / 1252310$

Azizan, N. A. and Mohamed, B. (2013), "The effects of perceived service quality on patient satisfaction at a public hospital in state of Pahang, Malaysia", Asian Journal of Social Sciences \& Humanities, 2 3, 307-23

Babakus, E. and Mangold, W. G. (1992), "Adapting the SERVQUAL scale to hospital services: An empirical investigation", Health Services Research, 26 6, 767-86

Bánfai B. - Deutsch K. - Petőné Csima M. - Jeges S. - Domina-Táncsics D. - Betlehem J. - Lampek K. (2015), „A hétévesnél fiatalabb gyermeket nevelő szülők háziorvosokkal való elégedettsége Magyarországon", Orvosi Hetilap, 156 31, 1253-60 DOI: 10.1556/650.2015.30189

Belicza É. - Zékány Zs. (1998), A minőség fogalmi rendszere az egészségügyben, EMIKK füzetek, Debrecen, 17. szám

Bjertnaes, O. A., Lyngstad, I., Malterud, K. and Garrat, A. (2011), ’The Norwegian EUROPEP questionnaire for patient evaluation of general practice: data quality, reliability and construct validity", Family Practice, 28 3, 342-49. DOI: https://doi.org/10.1093/fampra/cmq098

Boquuiren, V. M., Hack, T. F., Beaver, K. and Williamson, S. (2015), "What do measures of patient satisfaction with the doctor tell us?", Patient Education and Counseling, 98 12, 1465-73. DOI: https://doi.org/10.1016/j. pec. 2015.05 .020

Bowling, A., Rowe, G. and Mckee M. (2013), 'Patients' experiences of their healthcare in relation to their expectations and satisfaction: a population survey", Journal of the Royal Society of Medicine, 106 4, 143-9 DOI: https://doi. org/10.1258/jrsm.2012.120147

Buyukozkan, G., Cifci, G. and Guleryuz, S. (2011), "Strategic analysis of healthcare service quality using fuzzy AHP methodology", Expert Systems with Applications, 38 8, 9407-24 DOI: 10.1016/j.eswa.2011.01.103

Churchill, G. and Surprenant, C. (1982), "An Investigation into the Determinants of Cus- 
tomer Satisfaction", Journal of Marketing Research, 19 4, 491-504 DOI: http://dx.doi. org/10.2307/3151722

Cronin, J. J. and Taylor, S. T. (1992), "Measuring Service Quality: A Reexamination and Extention", Journal of Marketing, 56 3, 55-68. DOI: https://doi.org/10.2307/1252296

Dick, A. S. and Basu, K. (1994), "Consumer loyalty: toward an integrated conceptual framework", Journal of the Academy of Marketing Science, 22 2, 99-113 DOI: https://doi. org/10.1177/0092070394222001

Ferguson, R, Paulin, M., Pigeassou, C. and Gauduchon, R. (1999), "Assessing service management effectiveness in a health resort: implications of technical and functional quality", Managing Service Quality: An International Journal, 9 1, 58-65 DOI: https://doi. org/10.1108/09604529910248821

Fiala, T. G. (2012), "What Do Patients Want? Technical Quality versus Functional Quality: A Literature Review for Plastic Surgeons", Aesthetic Surgery Journal, 32 6, 751-9 DOI: 10.1177/1090820X12452555

Fisk, R. P., Brown and S. W., Bitner, M. J. (1993), "Tracking the evolution of the services marketing literature", Journal of Retailing, 691 , 61-103. DOI: 10.1016/S0022-4359(05)80004-1

Gavran, L., Jašarević, E. and Hasanica, N. (2013), "Patient satisfaction with primary care: are there differences between the approaches in family and general medicine? Medicinski Glasnik, 10 2, 379-84.

Gődény S. (2012), „Minőségbiztosítás és minőségfejlesztés az egészségügyi ellátás területén", in: Ádány R. (szerk.), Megelöző orvostan és népegészségtan, Budapest: Medicina Kiadó, 690-704

Grönroos, C. (1992), ”How quality came to service and where it is going", Paper presented at The Quality in Services conference. QUIS-3, University of Karlstad, Sweden

Grytten, J., Carlsen, F. and Skau I. (2009), "Services production and patient satisfaction in primary care", Health Policy, 89 3, 312-21 DOI: https://doi.org/10.1016/j.healthpol.2008.06.006

Haenlein, M. and Kaplan, A. M. (2004), "A Beginner's Guide to Partial Least Squares Analysis", Understanding Statistics, 3 4, 283-97. DOI: https://doi.org/10.1207/s15328031us0304_4

Hair, J. F., Ringle, C. M. and Sarstedt, M. (2011), "PLS-SEM: Indeed a Silver Bullet", Journal of Marketing Theory and Practice, 19 2, 139 51 DOI: https://doi.org/10.2753/MTP10696679190202
Hair, J. F., Black, W. C., Babin, B. J. and Anderson, R. E. (2009), "Multivariate Data Analysis", Prentice Hall, Upper Saddle River, NJ

Hetesi E. (2003), „A minőség, az elégedettség és a lojalitás mérésének problémái a szolgáltatásoknál, és azok hatása a jövedelmezőségre", Marketing \& Menedzsment, 37 5, 42-50

Hetesi E. - Rekettye G. (2001), „A lakossági ügyfelek lojalitásának mérése és elemzése egy magyar energiaszolgáltatónál", Vezetéstudomány, 32 9, 17-24

Hofmeister-Tóth Á. - Simon J. - Sajtos L. (szerk.), A fogyasztói elégedettség, Budapest: Alinea Kiadó, 2003

Illei Gy. (2011), „Menedzsment az egészségügyi gyakorlatban", in Boncz I. (szerk.), Egészségügyi finanszírozási, menedzsment és minőségbiztosítási ismeretek, Budapest: Medicina Kiadó

Jones, T. O., Sasser, Jr. W. E. (1995), ’Why satisfied customer defect?", Harvard Business Review, 73 6, 88-99

Kazár K. (2014), „A PLS-útelemzés alkalmazása egy márkaközösség pszichológiai érzetének vizsgálatára", Statisztikai Szemle, 92 1, 33-52

Kenesei Zs. - Kolos K. (2014), Szolgáltatásmarketing-és menedzsment, Budapest: Alinea Kiadó

Kertész A. - Balogh S. - Nagymajtényi L. - Paulik E. (2006), „A háziorvosi ellátással való elégedettség demográfiai sajátosságai”, Medicus Universalis, 39 4, 117-21

Kincsesné Vajda B. (2013), Kommunikációs, kapcsolati és egyéni tényezők az egészségügyi szolgáltatások minöségében és kimeneteiben, Doktori (PhD) értekezés, SZTE GTK

Kovács P. - Bodnár G. (2016), „Az endogén fejlődés értelmezése vidéki térségekben, a PLS-útelemzés segítségével", Statisztikai Szemle, 94 2, 143-61

Kroneman, M. W., Maarse, H, van der Zee, J. (2006), "Direct access in primary care and patient satisfaction: A European study", Health Policy, 76 1, 72-9. DOI: https://doi. org/10.1016/j.healthpol.2005.05.003

KSH, Statisztikai tükör. Európai lakossági egészségfelmérés, 2014. Budapest: Központi Statisztikai Hivatal, 2015

Lee, D.H. and Kim, K.K. (2017), "Assessing healthcare service quality: a comparative study of patient treatment types", International Journal of Quality Innovation, 3 1, 1-15. DOI: 10.1186/s40887-016-0010-5

Macstravic S. (1994), "Patient loyalty to physicians", Journal of Health Care Marketing, 14 $4,53-6$ 
Manaf, N.H.A. and Nooi, P.S. (2009), "Patient satisfaction as an indicator of service quality in Malaysian public hospitals", Asian Journal on Quality, 10 1, 77-87.

Martensen, A., Grönholdt, L. and Kristensen, K. (2000), "The drivers of customer satisfaction and loyalty: cross industry findings from Denmark", Total Quality Management, 11 4-6, 544 53. DOI: $10.1080 / 09544120050007878$

Mosadeghrad, A.M., (2013), "Healthcare service quality: towards a broad definition", International Journal of Health Care Quality Assurance, 26 3, 203-19. DOI: 10.1108/09526861311311409

Mpinga, E.K. and Chastonay, P. (2011), "Satisfaction of patients: A right to health indicator?", Health Policy, 100 2-3, 144-50 DOI: 10.1016/j. healthpol.2010.11.001

Naidu, A. (2009), 'Factors affecting patient satisfaction and healthcare quality", International Journal of Health Care Quality Assurance, 22 4, 366-81 DOI: 10.1108/09526860910964834

Oliver, R. L. (1999), “Whence Consumer Loyalty?” Journal of Marketing, 63 (Special Issue), 33-44. DOI: $10.2307 / 1252099$

Paddison, C. A., Abel, G. A., Roland, M. O., Elliott, M. N., Lyratzopoulos, G. and Campbell J. L. (2015), ,Drivers of overall satisfaction with primary care: evidence from the English General Practice Patient Survey", Health Expectations, 18 5, 1081-92. DOI: 10.1111/hex.12081

Parasuraman, A., Zeithaml, V. A. and Berry, L. L. (1988), "SERVQUAL: a multiple item scale for measuring consumer perceptions of service quality", Journal of Retaling 64 1, 12-40.

Reichheld, F. F. (1996), The Loyalty Effect. Boston, MA: Harvard Business School Press.

Säilä, T., Mattila, E., Kaila, M., Aalto, P. and Kaunonen, M. (2008), "Measuring patient assessments of the quality of outpatient care: a systematic review", Journal of Evaluation in Clinical Practice, 14 1, 148-54 DOI: 10.1111/j.13652753.2007.00824.x

Simon J. (2010), Marketing az egészségügyben, Budapest: Akadémiai Kiadó

Spreng, R. A. and Olshavsky, R. W. (1993), "A Desires Congruency Model of Consumer Satisfaction" Journal of the Academy of Marketing Science, 21 3, 196-217. DOI: http://dx.doi. org/10.1177/0092070393213001

Stewart, T. A. (1997), "A Satisfied Customer Isn’t Enough", Fortune, 136 2, 112-13

Szatmári M. (2009), „Betegelégedettség alapellátási praxisokban", Medicus Universalis, 42 $5,179-82$
Szatmári M., Sonkoly I., Balogh S. (2010), „Alapellátási tükör 5007 betegelégedettségi kérdőív alapján”, Medicus Universalis, 43 4, 137-9

Tse, D. and Wilton, P. (1988), "Models of Consumer Satisfaction Formation: An Extension", Journal of Marketing Research, 25 2, 204-12. DOI: $10.2307 / 3172652$

Vajda B. Horváth S. Málovics É. (2012), „Közös döntéshozatal, mint innováció az orvos beteg kapcsolatban”, in: Málovics Gy. (szerk.), Regionális innovációs képesség, versenyképesség és fenntarthatóság, Szeged: JATEPress, 336-53

Veres Z., A szolgáltatásmarketing alapkönyve, Budapest: Akadémiai Kiadó, 2009

Veres Z. - Hoffmann M. - Kozák Á. (szerk.), Bevezetés a piackutatásba, Budapest: Akadémiai Kiadó, 2016

Voss, G. B., Parasuraman, A., Grewal, D. (1998), "The Role of Price, Performance, and Expectations in Determining Satisfaction in Service Exchanges", Journal of Marketing, 62 4, 46-61

Weitzman, B. C. In: Kovner, A. R. Health care delivery in the United States, (5th ed.). Berlin: Springer, 1995

Zeithaml, V. A. (2000), "Service Quality, Profitability, and the Economic Worth of Customers: What We Know and What We Need to Learn?", Journal of the Academy of Marketing Science, 28 1, 67-85. DOI: 10.1177/0092070300281007 
Juhász Zoltán PhD, tanársegéd juhasz.zoltan@med.u-szeged.hu

Szegedi Tudományegyetem Általános Orvostudományi Kar Egészség-gazdaságtani Intézet

Dr. habil. Hetesi Erzsébet PhD, egyetemi tanár hetesi@eco.u-szeged.hu Szegedi Tudományegyetem Gazdaságtudományi Kar Üzleti Tudományok Intézete

Dr. habil Buzás Norbert PhD, tanszékvezető egyetemi docens buzas.norbert@med.u-szeged.hu

Szegedi Tudományegyetem Általános Orvostudományi Kar Egészség-gazdaságtani Intézet

\section{Investigation of factors influencing patients' satisfaction and loyalt in the primary care}

\section{THE AIM OF THE PAPER}

Our study deals with the influencing factors of patients' satisfaction with their primary care physicians, and with satisfaction-loyalty connection. We investigated which service-quality items may influence the best the satisfaction with the primary care and whether the satisfaction has an effect on the loyalty to the physician.

\section{METHODOLOGY}

Data were collected by interviews using nationally and internationally validated questionnaires. The sample was chosen from inhabitants of three different cities. The data was processed by IBM SPSS Statistics 24 and SmartPLS programmes. The sample was evaluated with mathematical-statistical methods: descriptive statistics, one-way ANOVA, and PLS Path Modeling.

\section{MOST IMPORTANT RESULTS}

The satisfaction results of this paper can be compared with similar national publications. $80 \%$ of respondents were still satisfied or very satisfied with their family physicians. Their average performance was 4,27 measured on a five-point Liker-scale.

According to PLS regression results, the satisfaction of patients is influenced remarkably by the involvement of patients into decision-making $(\beta=0,459)$ and providing information to patients $(\beta=0,210)$, but the role of the physical environment is not a relevant factor in satisfaction. Our novel finding is that patient-physician communication significantly influence the overall satisfaction. Moreover, a linear correlation was also proved between satisfaction and loyalty $(\beta=0,727)$.

\section{RECOMMENDATIONS}

The results of the present research highlight new aspect of quality improvement factors in the everyday practice. Besides the conventional quality dimensions in the primary care (waiting times, physical environment) newer items appeared as relevant factors (communication, patient involvement). Based on our results, the directions of practice development can be appointed: the good patient-physician communication, handling patients as equal partner and involvement of the patient into the decision-making process should play a crucial role in the future.

Keywords: family physician; satisfaction; loyalty; practice development; physician-patient 